\title{
Effects of progesterone concentrations and follicular wave during growth of the ovulatory follicle on conceptus and endometrial transcriptome in dairy cows
}

\author{
R. S. Bisinotto, ${ }^{1,2 *} \odot$ E. S. Ribeiro, ${ }^{3} \odot$ L. F. Greco, ${ }^{4}$ D. Taylor-Rodriguez, ${ }^{5}$ A. D. Ealy, ${ }^{6} \oplus$ H. Ayres, ${ }^{4}$ F. S. Lima, ${ }^{7} \oplus$ \\ N. Martinez, ${ }^{4}$ W. W. Thatcher, ${ }^{2,4}$ and J. E. P. Santos ${ }^{2,4}$ \\ ${ }^{1}$ Department of Large Animal Clinical Sciences, University of Florida, Gainesville 32610 \\ ${ }^{2}$ D. H. Barron Reproductive and Perinatal Biology Research Program, University of Florida, Gainesville 32610 \\ ${ }^{3}$ Department of Animal Biosciences, University of Guelph, Guelph, ON N1G 2W1, Canada \\ ${ }^{4}$ Department of Animal Sciences, University of Florida, Gainesville 32611 \\ ${ }^{5}$ Department of Mathematics and Statistics, Portland State University, Portland, OR 97201 \\ ${ }^{6}$ Department of Animal and Poultry Sciences, Virginia Polytechnic Institute and State University, Blacksburg 24060 \\ ${ }^{7}$ Department of Population Health and Reproduction, University of California-Davis, Davis 95616
}

\begin{abstract}
Objectives were to evaluate the effects of follicular wave and progesterone concentration on growth of the ovulatory follicle, conceptus elongation, uterine IFN- $\tau$ concentration, and transcriptome of conceptus and endometrium of pregnant cows on d 17 of gestation. Nonlactating nonpregnant Holstein cows were assigned randomly to one of 3 treatments: ovulation of a firstwave follicle $(\mathrm{FW}, \mathrm{n}=15)$; ovulation of a first-wave follicle and progesterone supplementation (FWP4, n $=12$ ); and ovulation of a second-wave follicle ( $\mathrm{SW}$, $\mathrm{n}=19$ ). Ovulation of a first- or second-wave follicle was achieved by initiating the Ovsynch protocol ( $\mathrm{d}-9$ GnRH, d -2 and $-1 \mathrm{PGF}_{2 \alpha}$, d $0 \mathrm{GnRH}$ and artificial insemination, d 0.7 artificial insemination) on d 0 or 6 of a presynchronized estrous cycle, respectively. Cows in FWP4 received 3 intravaginal inserts containing progesterone at 12,24 , and $48 \mathrm{~h}$ after the first $\mathrm{GnRH}$ injection that were removed on $\mathrm{d}-2$. Cows were killed on d 17 for collection of the reproductive tract. Transcriptome was evaluated by microarray using the Affymetrix Bovine Array. Orthogonal contrasts were built to assess the effects of progesterone concentration during follicle growth (FW vs. FWP4 + SW) and follicular wave (FWP4 vs. SW). Progesterone concentrations (LSM \pm SEM) from $\mathrm{d}-9$ to -2 were greater for $\mathrm{SW}$, followed by FWP 4 and FW $(5.38 \pm 0.24,4.26 \pm 0.28$, and 1.17 $\pm 0.27 \mathrm{ng} / \mathrm{mL}$ ). Diameter of the ovulatory follicle (FW $=19.6 \pm 0.6 ; \mathrm{FWP} 4=15.6 \pm 0.6 ; \mathrm{SW}=15.2 \pm 0.5$ $\mathrm{mm}$ ) and concentrations of estradiol from $\mathrm{d}-2$ to 1 $(\mathrm{FW}=4.05 \pm 0.33 ; \mathrm{FWP} 4=2.73 \pm 0.35 ; \mathrm{SW}=2.48$
\end{abstract}

Received January 20, 2021.

Accepted June 21, 2021

*Corresponding author: rsbisinotto@ufl.edu $\pm 0.30 \mathrm{pg} / \mathrm{mL}$ ) were greater for $\mathrm{FW}$ compared with FWP4 and SW. Progesterone concentrations from d 3 to 16 were greater for FW compared with FWP4 and SW. A total of 28 singleton conceptuses were collected $(\mathrm{FW}, \mathrm{n}=8 ; \mathrm{FWP} 4, \mathrm{n}=8 ; \mathrm{SW}, \mathrm{n}=12)$ and only intact conceptuses were included in the analyses of length (FW, $\mathrm{n}=8$; FWP4, $\mathrm{n}=6$; $\mathrm{SW}, \mathrm{n}=12)$. Although conceptuses were longer for FW compared with FWP4 and $\mathrm{SW}(\mathrm{FW}=16.6 \pm 2.3 ; \mathrm{FWP} 4=9.8 \pm 2.2 ; \mathrm{SW}=$ $9.6 \pm 2.0 \mathrm{~cm})$, treatment did not affect the amount of IFN- $\tau$ in uterine flushing. Transcriptome of conceptuses and endometrium of pregnant cows was not extensively affected by follicular wave ( 8 and 1 differentially expressed transcripts) or concentration of progesterone during follicle growth (0 and 3 differentially expressed transcripts), showing that these factors did not affect conceptuses and endometrium transcriptome in pregnancies that are maintained to $\mathrm{d} 17$.

Key words: corpus luteum, embryo, reproduction, gene expression

\section{INTRODUCTION}

Pregnancy loss is one of the main limitations for achievement of optimal fertility in dairy cows. Successful fertilization is observed in approximately $80 \%$ of dairy cows subjected to AI. However, $60 \%$ of zygotes are expected to die before term, which means the proportion of inseminated cows that calve often is below 30\% (Santos et al., 2004; Wiltbank et al., 2016). Embryonic death is particularly important within the first $28 \mathrm{~d}$ of insemination, when $75 \%$ of all pregnancy losses are observed (Santos et al., 2004). Establishment of pregnancy is a coordinated process that entails a delicate crosstalk between the embryonic and maternal components. Bovine conceptuses must be able to elon- 
gate rapidly and produce IFN- $\tau$ to block the luteolytic cascade (Thatcher et al., 1989). Nutrients and growth factors secreted by endometrial glands, collectively known as histotroph, are essential for conceptus elongation after hatching from the zona pellucida (Filant and Spencer, 2014). In turn, conceptus-derived IFN- $\tau$ and prostaglandins control the expression of IFN-stimulated genes both locally and systemically (Gifford et al., 2007, 2008; Spencer et al., 2013). Altogether, the interaction between conceptus and endometrium leads to the maintenance of a functional corpus luteum (CL), immune modulation and receptivity to pregnancy, adhesion of the trophectoderm to the endometrium, and subsequent implantation (Spencer et al., 2008). Understanding the factors that disrupt this communication is critical to mitigate pregnancy loss and enhance individual fertility in dairy cows.

Insufficient concentration of progesterone in plasma during the growth of the ovulatory follicle substantially reduces pregnancy per AI (P/AI) in dairy cows (Bisinotto et al., 2014; Wiltbank et al., 2014). Cows induced to ovulate the dominant follicle from the first wave, which develops concurrently with the CL and, thus, under reduced concentrations of progesterone, are $30 \%$ less likely to become pregnant compared with those that ovulate a second-wave follicle (Bisinotto et al., 2010; Denicol et al., 2012). Cows that lack a functional CL at the initiation of a timed AI protocol also have reduced concentrations of progesterone in plasma and lesser $\mathrm{P} /$ AI compared with herdmates in diestrus (Bisinotto et al., 2013, 2015). More importantly, supplementing progesterone to increase progesterone concentrations in plasma above $2 \mathrm{ng} / \mathrm{mL}$ restored fertility in cows lacking CL when the timed AI program was initiated (Bisinotto et al., 2013, 2015). Although these results support the importance of progesterone for proper follicle maturation and subsequent embryo survival, the exact mechanisms implicated in such process remain undefined (Santos et al., 2016). Reduced concentrations of progesterone during the first wave are associated with greater frequency of LH pulses and expedited follicular growth compared with that observed during the second wave (Endo et al., 2012). Furthermore, cows induced to have reduced concentrations of progesterone during development of the ovulatory follicle had increased LH concentrations in plasma, faster rate of follicular growth, and smaller intra-follicular concentrations of IGF-1 (Cerri et al., 2011a). Such changes in follicular growth and intrafollicular environment have been associated with decreased number of live blastomeres, impaired embryo quality, and increased proportion of degenerated embryos on d 7 after AI (Cunha et al., 2008; Cerri et al., 2011b; Rivera et al., 2011). Nevertheless, the effects of follicular wave and progesterone concentrations during growth of the ovulatory follicle on development of elongating conceptuses during preimplantation stages remain largely unknown.

In addition to its effects on follicle maturation and embryo quality, reduced progesterone concentrations before ovulation likely have a legacy effect on uterine function in the subsequent estrous cycle. Cows with reduced progesterone concentration during the growth of the ovulatory follicle had greater release of $\mathrm{PGF}_{2 \alpha}$ in response to oxytocin (Shaham-Albalancy et al., 2001; Cerri et al., 2011a) and altered uterine vascularization and endometrial gland morphology (Shaham-Albalancy et al., 1997). Interestingly, the ovulation of follicles that developed under low concentrations of progesterone resulted in larger CL on d 6 after AI (Cerri et al., 2011b), which has been associated with greater concentrations of progesterone after ovulation (Vasconcelos et al., 2001). Nevertheless, it remains unexplored whether a faster rise in progesterone concentrations after AI offsets the negative effect of ovulating a first-wave dominant follicle or creates an asynchrony between conceptus and endometrium by hastening progression of gene expression further disrupting the establishment of pregnancy in cows that ovulate first-wave follicles (Forde et al., 2009; O'Hara et al., 2014).

Objectives of the present experiment were to evaluate the effects of follicular wave and progesterone concentration during the growth of the ovulatory follicle on ovarian responses, conceptus elongation, concentrations of IFN- $\tau$ in uterine flush, and global gene expression in the endometrium and conceptus on d 17 of gestation. Our hypotheses were that the ovulation of first wave follicles disrupts conceptus elongation in dairy cows compared with the ovulation of follicles from the second wave, which would alter embryonic and endometrial gene expression and reduce concentrations of IFN- $\tau$ in the uterine flushing. Moreover, we hypothesized that these negative effects on embryo development and uterine receptivity to pregnancy are eliminated by supplementing cows with progesterone during the first follicular wave.

\section{MATERIALS AND METHODS}

All experimental procedures complied with the Guide for Care and Use of Agricultural Animals in Agricultural Research and Teaching and were approved by the Animal Research Committee of the University of Florida protocol number 018-09ANS.

\section{Cows and Eligibility for Enrollment}

Nonlactating and nonpregnant Holstein cows were kept on pasture and had access to shade and water ad 

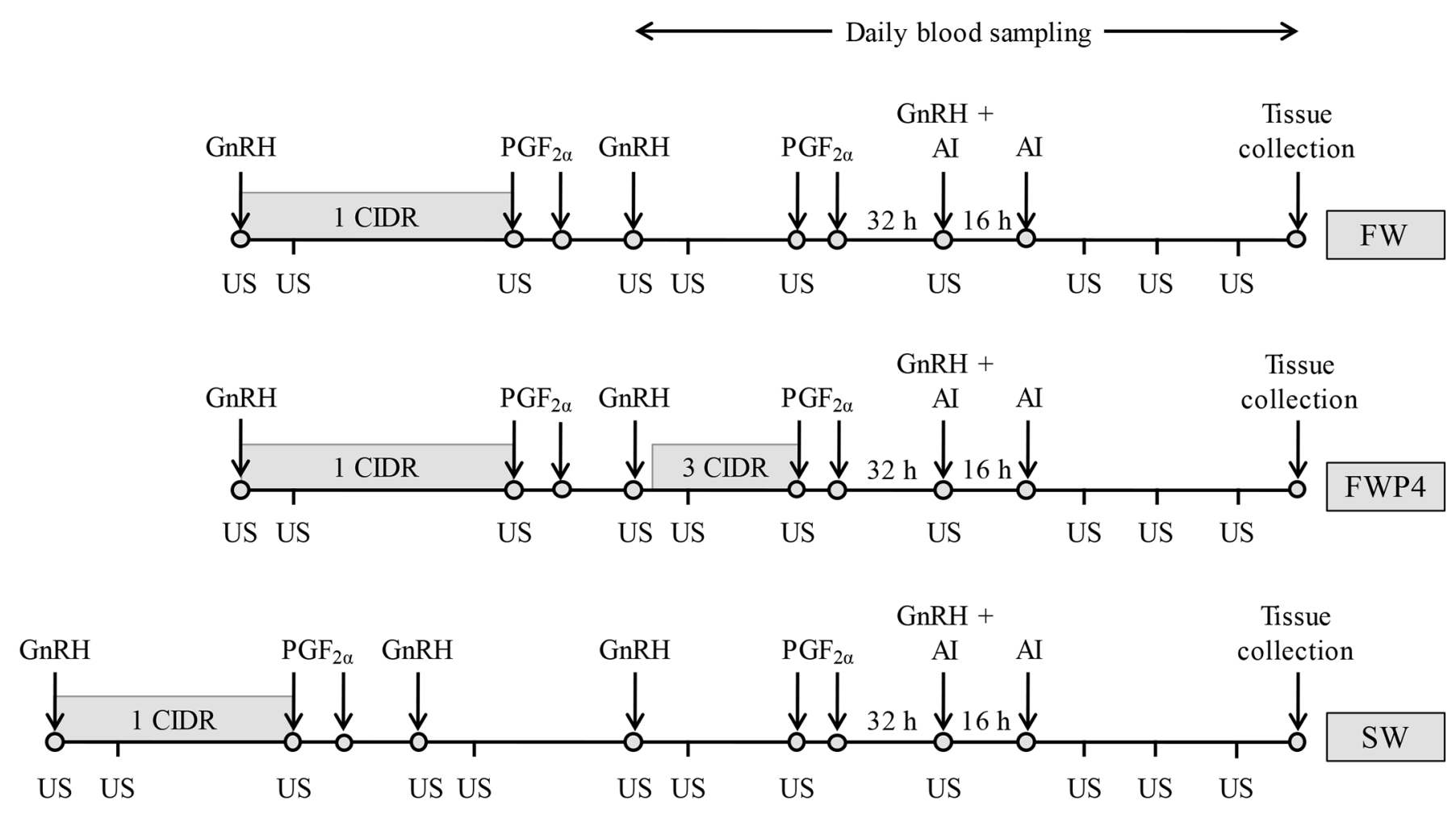

Study day

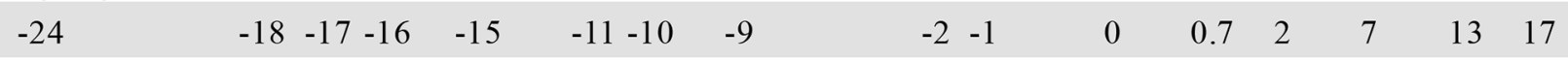

Figure 1. Diagram of experimental procedures. $\mathrm{FW}=$ cows induced to ovulate a first-wave follicle; FWP4 = cows induced to ovulate a first-wave follicle and treated with 3 controlled internal drug release (CIDR) inserts containing $1.38 \mathrm{~g}$ of progesterone each (inserted 12, 24, and $48 \mathrm{~h}$ after $\mathrm{GnRH}$ injection on $\mathrm{d}-9$ and removed on $\mathrm{d}-2$ ); $\mathrm{SW}=$ cows induced to ovulate a second-wave follicle. AI $=$ artificial insemination; $\mathrm{GnRH}=$ injection of $100 \mu \mathrm{g}$ of gonadotropin-releasing hormone; $\mathrm{PGF}_{2 \alpha}=$ injection of $25 \mathrm{mg}$ of prostaglandin $\mathrm{F}_{2 \alpha}$; US = evaluation of ovarian structures via transrectal ultrasonography (unless experiment day is indicated, US were performed $2 \mathrm{~d}$ after preceding GnRH injection).

libitum. Cows were fed a TMR containing corn silage, Bermuda grass silage, ground corn, citrus pulp, soybean meal, wet brewer's grains, minerals, and vitamins. Cows were transrectally palpated and those diagnosed with abnormal reproductive tracts (i.e., follicular cysts, adhesions, abscesses, tumors) were excluded from enrollment. Body condition was scored $7 \mathrm{~d}$ before the onset of presynchronization using a 1 to 5 scale with 0.25 increments (Elanco Animal Health, 2009).

\section{Experimental Design, Treatments, and Sample Size Calculation}

Eligible cows were stratified by parity group (primiparous or multiparous) and BCS and assigned randomly to one of 3 treatments as a completely randomized design (Figure 1). Treatments were ovulation of a first-wave follicle (FW); ovulation of a first-wave follicle concurrent with progesterone supplementation
(FWP4); ovulation of a second-wave follicle (SW). The treatment FWP4 was designed to mimic progesterone concentrations in plasma of those in SW, but have cows ovulate a first-wave dominant follicle.

A 2-sided sample size was calculated with the POWER procedure of SAS version 9.3 (SAS Institute Inc.). To adjust for possible multiple comparisons with 3 treatments, the value of $\alpha$ was set $0.017(\alpha=0.05 / 3$ $=0.017)$ and $\beta=0.20$. The sample size calculated of 11 cows per treatment allowed detection of statistical effect in ovulatory follicle diameter when a difference of $3.0 \mathrm{~mm}$ is observed assuming a standard deviation (SD) of $2.0 \mathrm{~mm}$ for follicle diameter based on data from previous experiments manipulating follicle progesterone concentrations during growth of the ovulatory follicle (Cerri et al., 2011a,b). Because not every cow was anticipated to respond to all hormonal treatments, additional cows were added to ensure at least 11 per treatment that synchronized. No sample size was cal- 
culated for number of conceptuses for transcriptome analyses because of an inability to determine expected differences and variance in the data. A previous cohort study in our group observed large differences in transcriptome in d 15 conceptuses between anovular cows, that ovulated to first-wave follicles, or estrous cyclic cows that ovulated follicles that developed under high concentration of progesterone with 6 elongated conceptuses analyzed per treatment (Ribeiro et al., 2016b). To ensure that at least 6 or 7 elongated conceptuses would be recovered on $\mathrm{d} 17$ in each treatment, the experiment enrolled at least 13 cows per treatment. The unequal number of cows per treatment was caused by some cows not responding to one of the hormonal treatments during estrous synchronization protocols (Figure 1). Cows diagnosed with double ovulation on d 0 were not included in the statistical analyses $(\mathrm{FW}, \mathrm{n}=1 ; \mathrm{FWP} 4$, $\mathrm{n}=1)$. Therefore, 46 cows (FW, $\mathrm{n}=15$; FWP $4, \mathrm{n}=$ 12 ; SW, $\mathrm{n}=19$ ) were considered for statistical analyses of ovarian responses and hormonal concentrations, whereas 28 pregnant cows carrying singletons (FW, $\mathrm{n}=8 ; \mathrm{FWP} 4, \mathrm{n}=8 ; \mathrm{SW}, \mathrm{n}=12$ ) were considered for statistical analyses of conceptus and endometrial transcriptome.

\section{Synchronization of the Estrous Cycle}

The estrous cycle of cows was presynchronized with an injection of $\mathrm{GnRH}(100 \mu \mathrm{g}$ of gonadorelin diacetate tetrahydrate, i.m., Cystorelin, Merial Ltd.) and a controlled internal drug release (CIDR) insert (1.38 g of progesterone, Eazi-Breed CIDR, Pfizer Animal Health). Inserts were removed $7 \mathrm{~d}$ later and cows received 2 $\mathrm{PGF}_{2 \alpha}$ injections (25 $\mathrm{mg}$ of dinoprost tromethamine, i.m., Lutalyse, Pfizer Animal Health) 24 h apart. Cows received a second $\mathrm{GnRH}$ injection $1 \mathrm{~d}$ after the second $\mathrm{PGF}_{2 \alpha}$. The experimental synchronization protocol (d -9 GnRH, d -2 and $-1 \mathrm{PGF}_{2 \alpha}$, d $0 \mathrm{GnRH}$ ) was initiated either on the same day of the second GnRH injection of the presynchronization in treatments $\mathrm{FW}$ and FWP4, or $6 \mathrm{~d}$ after the second GnRH injection of the presynchronization in SW. Cows assigned to FWP4 received 3 CIDR inserts given singularly at 12,24 , and $48 \mathrm{~h}$ after the injection of $\mathrm{GnRH}$ administered on $\mathrm{d}-9$. All inserts were removed on $\mathrm{d}-2$. Cows in all treatments were inseminated using frozen-thawed semen concurrently with the final GnRH injection (d 0) and $16 \mathrm{~h}$ later (d 0.7). Two sires of high sire conception rate were used and distributed equally among treatments. Only cows that responded to all hormonal treatments based on ultrasonographic (Aloka SSD-500 equipped with a $7.5 \mathrm{MHz}$ linear transducer, Aloka Co.) evaluation of the ovaries were kept in the experiment.

\section{Ultrasonographic Evaluation of Ovaries}

Ovaries were evaluated by ultrasonography to ensure response to hormonal treatments and for the measurement of ovarian structures (Figure 1). Position and diameter of all follicles $>5 \mathrm{~mm}$ and CL were recorded at each examination. Ovulation was defined as the disappearance of one or more follicles $\geq 8.5 \mathrm{~mm}$ within $2 \mathrm{~d}$ of a GnRH injection followed by the formation of a CL in the same location. Structural luteolysis was defined as the disappearance of a CL within $4 \mathrm{~d}$ of a $\mathrm{PGF}_{2 \alpha}$ injection. The largest diameter of the ovulatory follicle was measured on $\mathrm{d}-2$ and 0 . The volume of the CL was evaluated on d 7 and 13. At the largest cross-section, the width and height of the CL and its cavity were measured. Average radiuses were used for calculation of CL volume as $\left(4 / 3 \times \pi \times R_{C L}^{3}\right)-\left(4 / 3 \times \pi \times R_{\text {cavity }}^{3}\right)$,

where $R_{C L}$ is the average radius of the CL, $R_{\text {cavity }}$ is the average radius of the cavity, and $\pi=3.14159$.

\section{Analyses of Progesterone and Estradiol Concentrations in Plasma}

Blood was sampled daily from d -9 to 17 by puncture of the coccygeal vessels using evacuated tubes with $\mathrm{K}_{2}$ EDTA (Vacutainer, Becton Dickinson). Blood tubes were placed on ice immediately and centrifuged at $2,000 \times g$ for $15 \mathrm{~min}$ at $4^{\circ} \mathrm{C}$ within $2 \mathrm{~h}$ of collection. Plasma samples were frozen at $-20^{\circ} \mathrm{C}$ until assayed. Concentrations of progesterone from d -9 to 17 were analyzed by radioimmunoassay using a commercial kit (Coat-a-Count, Siemens Healthcare Diagnostics). The average sensitivity of the assay calculated at 2 SD below the mean counts per minute at maximum binding was $0.02 \mathrm{ng} / \mathrm{mL}$. Intra- and interassay coefficients of variation were calculated based on samples with known progesterone concentrations $(1.5$ and $2.5 \mathrm{ng} / \mathrm{mL})$ and averaged 7.1 and $9.1 \%$, respectively. Concentrations of estradiol in plasma were analyzed from $\mathrm{d}-2$ to $\mathrm{d} 1$ by radioimmunoassay using a commercial kit (Estradiol Double Antibody, Siemens Healthcare Diagnostics) validated for use in bovine samples (Siddiqui et al., 2009). The average sensitivity of the assay calculated at 2 SD below the mean counts per minute at maximum binding was $0.17 \mathrm{pg} / \mathrm{mL}$. All samples were analyzed in duplicate and the intra-assay coefficient of variation averaged $10.7 \%$. The interassay coefficient of variation calculated based on the plasma from a cow exhibiting standing estrous activity $(\sim 7.5 \mathrm{pg} / \mathrm{mL})$ was $14.3 \%$. Cows whose greatest estradiol concentration was observed before the injection of GnRH administered on d 0 were considered to have a premature peak of estradiol. 


\section{Uterine Flush and Collection of Conceptus and Endometrial Tissue}

Cows were euthanized via penetrating captive bolt followed by exsanguination on experiment d 17. Reproductive tracts were collected, immediately placed on ice, and processed within $2 \mathrm{~h}$ of collection. The uterine horn ipsilateral to the CL was dissected from the intercornual and broad ligaments, then isolated from the contralateral horn using a Doyen forceps. The cervix was closed using a string tight between 2 rings proximal to the uterine body. A transversal incision on the uterine horn was performed approximately $2 \mathrm{~cm}$ before the uterotubal junction and the ipsilateral horn was flushed with $30 \mathrm{~mL}$ of sterile Dulbecco's phosphate-buffered saline (DPBS) solution using a 14-gauge needle coupled to a $60-\mathrm{mL}$ syringe. The needle was inserted at base of the ipsilateral horn, and DPBS solution was injected gently. Uterine flush was collected through the transversal incision into a petri dish and evaluated for the presence of a conceptus under microscope. Pregnancy was defined as the presence of a conceptus recovered by uterine flushing on $\mathrm{d} 17$. Conceptuses were measured, snap-frozen in liquid $\mathrm{N}_{2}$, and stored at $-80^{\circ} \mathrm{C}$. The remaining fluid was cleared by centrifugation at $2,000 \times g$ for $30 \mathrm{~min}$ at $4^{\circ} \mathrm{C}$, quantified, and stored at $-80^{\circ} \mathrm{C}$ until assayed. After flushing, the uterine horn was opened longitudinally using scissors and samples of intercaruncular endometrium were dissected, snapfrozen in liquid $\mathrm{N}_{2}$ and stored at $-80^{\circ} \mathrm{C}$. The uterine horn was visually divided into 3 sections (i.e., third proximal to the bifurcation, intermediate third, and third distal to the bifurcation), and an equal number of biopsies were collected from each section to ensure that the final sample was as representative of the entire horn as possible. Corpora lutea was dissected from the ovary and weighed.

\section{RNA Extraction and Transcriptome Analysis}

Total RNA extraction was performed using TRIzol reagent (Invitrogen) and a commercial kit for RNA purification (PureLink RNA Mini Kit, Invitrogen) according to recommendations provided by the manufacturer. Endometrial samples were homogenized using a handheld rotor-stator homogenizer (Qiagen). Concentration of RNA was analyzed using a microvolume spectrophotometer (NanoDrop 2000, Thermo Fisher Scientific). Quality of RNA was assessed using the Agilent 2100 Bioanalyzer (Agilent Technologies Inc.) and only samples with RNA integrity numbers greater than 7 were considered for subsequent transcriptome evaluation. Microarray analyses were conducted at the
Interdisciplinary Center for Biotechnology Research, University of Florida. Samples were prepared using the GeneChip 3' IVT Express kit (Affymetrix Inc.) according to manufacturer's protocols and hybridized to the Affymetrix GeneChip Bovine array. Arrays were washed and stained using the Affymetrix GeneChip Hybridization Wash and Stain kit in the Affymetrix Fluidics Station 450. Scanning of arrays was performed using the Affymetrix GeneChip 7G Scanner.

\section{Measurement of IFN-T in Uterine Flush}

Concentrations of IFN- $\tau$ in the uterine flush were determined using a luciferase-based interferon stimulatory response element reporter gene assay in MDBK cells as described previously (McCoski et al., 2014). Recombinant human IFN- $\alpha\left(3.87 \times 10^{8} \mathrm{IU} / \mathrm{mg} ; \mathrm{EMD}\right.$ Biosciences) was used to build the standard curves and $50 \mu \mathrm{L}$ of One-Glo Luciferase Assay Substrate (Promega Corp.) was added to each well to determine luciferase activity. An initial run was performed to define the optimal range of dilution for each sample. All samples were analyzed in triplicate, assay sensitivity was 0.3 $\mathrm{ng} / \mathrm{mL}$ and the intra-assay coefficient of variation averaged $18.5 \%$.

\section{Statistical Analyses}

Continuous data were analyzed by ANOVA using the GLIMMIX procedure of SAS version 9.3 (SAS Institute Inc.) fitting a normal distribution. The fixed effects of treatment, parity, and the interaction between treatment and parity were included as independent variables. Concentrations of progesterone and estradiol were analyzed as repeated measures by ANOVA using the GLIMMIX procedure of SAS fitting a normal distribution. The effects of treatment, parity, day, and the interactions between treatment and parity, and treatment and day were included in the model as independent variables. Cow nested within treatment was considered a random effect. The covariance structure that resulted in the smallest Schwarz's Bayesian information criterion value was selected for each analysis. Normality of residues, homogeneity of variances, and possible outliers were assessed by visual evaluation of Q-Q plots, histograms of the distribution of residuals, and scatter plots of studentized residuals against predicted values. Data that did not fulfill the assumptions for ANOVA were subjected to power transformation accordingly. Binary responses were analyzed by multivariable logistic regression using the GLIMMIX procedure of SAS fitting a binary distribution with a logit link. Initial models included the fixed effects of treatment, parity, 
and the interaction between treatment and parity. The effects of the interaction between treatment and parity and that of parity were sequentially removed from the statistical models by backward elimination if $P>$ 0.10. The $P$-values for all pairwise comparisons among treatments were adjusted using the Tukey method. Orthogonal contrasts were used to evaluate the effects of concentrations of progesterone during the development of the ovulatory follicle (FW vs. FWP4 + SW) and follicular wave (FWP4 vs. SW). Differences with $P \leq$ 0.05 were considered significant and those with $0.05<$ $P \leq 0.10$ were considered tendencies.

Quality of microarray was analyzed using Affymetrix internal controls with the ArrayAnalysis.org tool (Eijssen et al., 2013) and no indication of RNA degradation or technical issues were observed. Processing of CEL files and statistical analyses were conducted using the Bioconductor repository in R. The Guanidine-Cytosine Robust Multichip Average method was used for array normalization, background correction, and summarization of probesets (Wu et al., 2004). Adjustment for batch effects was implemented using a parametric empirical Bayes method as described previously (Johnson et al., 2007). Expression data were analyzed using robust regression within the Linear Models for Microarray library (Smyth, 2004) and the statistical model included the fixed effect of treatment. Orthogonal contrasts were used to evaluate the effects of concentration of progesterone and follicular wave during growth of the ovulatory follicle as described previously. The $P$-values were adjusted for multiple hypotheses testing to limit the false discovery rate at 5\% (Benjamini and Hochberg, 1995). Genes with adjusted $P \leq 0.05$ and fold changes $\geq 1.5$ were considered differentially expressed. Biological functions associated with differentially expressed genes were explored using the Database for Annotation, Visualization, and Integrated Discovery bioinformatics resources (Huang et al., 2009).

\section{RESULTS}

\section{Hormonal Concentrations and Ovarian Structures}

Concentrations of progesterone in plasma during the development of the ovulatory follicle differed among treatments (Figure 2). Cows in FW and FWP4 had lesser $(P<0.001)$ progesterone concentrations on $\mathrm{d}-9$ compared with SW cows $(\mathrm{FW}=0.36 \pm 0.13$; FWP4 $=$ $0.23 \pm 0.15 ; \mathrm{SW}=2.12 \pm 0.12 \mathrm{ng} / \mathrm{mL})$. However, no difference $(P=0.79)$ in progesterone concentration on $\mathrm{d}-9$ was observed between FW and FWP4. Insertion of 3 CIDR devices increased $(P<0.001)$ concentrations of progesterone in plasma in FWP4 that reached a plateau on $\mathrm{d}-6$, whereas cows in $\mathrm{FW}$ and $\mathrm{SW}$ had a continuous increase in progesterone concentrations in plasma until $\mathrm{d}-2$ when $\mathrm{PGF}_{2 \alpha}$ was administered. From $\mathrm{d}-8$ to -2 , progesterone concentrations were lesser $(P$ $<0.0001)$ for FW compared with FWP4 and SW and tended to be lesser $(P=0.10)$ for FWP4 compared with SW. Progesterone concentration on $\mathrm{d}-1$ did not differ $(P=0.46)$ between $\mathrm{FW}$ and FWP4, however, it was greater $(P \leq 0.02)$ for $\mathrm{SW}$ compared with $\mathrm{FW}$ and FWP4 $(\mathrm{FW}=0.50 \pm 0.07 ; \mathrm{FWP} 4=0.38 \pm 0.08 ; \mathrm{SW}$ $=0.76 \pm 0.06 \mathrm{ng} / \mathrm{mL})$. Treatment did not affect $(P$ $=0.59)$ concentrations of progesterone on $\mathrm{d} 0(\mathrm{FW}=$ $0.30 \pm 0.05 ; \mathrm{FWP} 4=0.26 \pm 0.05 ; \mathrm{SW}=0.36 \pm 0.04$ $\mathrm{ng} / \mathrm{mL})$.

Diameter of the ovulatory follicle on $\mathrm{d}-2$ and 0 was greater $(P<0.001)$ for FW compared with FWP4 and SW (Table 1). Although follicular wave tended to affect $(P=0.06)$ diameter of the ovulatory follicle on $\mathrm{d}-2$, no difference between FWP4 and SW was observed on d 0. Maximal concentration of estradiol from $d-2$ to 1 and the proportion of cows with premature peak of estradiol were greater $(P<0.01)$ for $\mathrm{FW}$ compared with FWP4 and SW (Table 1). Estradiol concentrations from $\mathrm{d}-2$ to 1 were affected $(P<0.001)$ by the interaction between treatment and day because $\mathrm{FW}$ had greater $(P<0.001)$ estradiol concentrations on $\mathrm{d}$ -1 compared with FWP4 and SW (Figure 3).

Number of CL per cow and the total CL volume on $d$ -2 were greater $(P<0.01)$ for SW compared with $\mathrm{FW}$ and FWP4. Luteal volume on $\mathrm{d} 7$ was affected $(P<$ 0.001 ) by progesterone during preovulatory follicle development, as CL volume was greater for FW compared with FWP4 and SW (Table 1). Both progesterone and follicle wave tended to affect $(P=0.10)$ CL volume on d 13, which was largest for FW, smallest for FWP4, and intermediate for SW. Corpus luteum weight on d 17 was affected by progesterone $(P<0.01)$ and follicle wave $(P=0.05)$ because cows in $\mathrm{FW}$ had heavier CL than those in FWP4 and SW, and cows in FWP4 had lighter CL than those in SW. None of the cows in the experiment underwent spontaneous luteolysis before $\mathrm{d}$ 17. Progesterone concentrations from d 3 to 16 were greater $(P<0.03)$ for FW compared with FWP4 and SW (Figure 4). On d 17, FW had greater concentrations of progesterone than FWP4 whereas no difference was observed between SW and either FW or FWP4.

\section{Conceptus Length and IFN-T Concentration in Uterine Flush}

Proportion of pregnant cows on d 17 was not affected by progesterone or follicular wave during the development of the ovulatory follicle (Table 2). Conceptus 


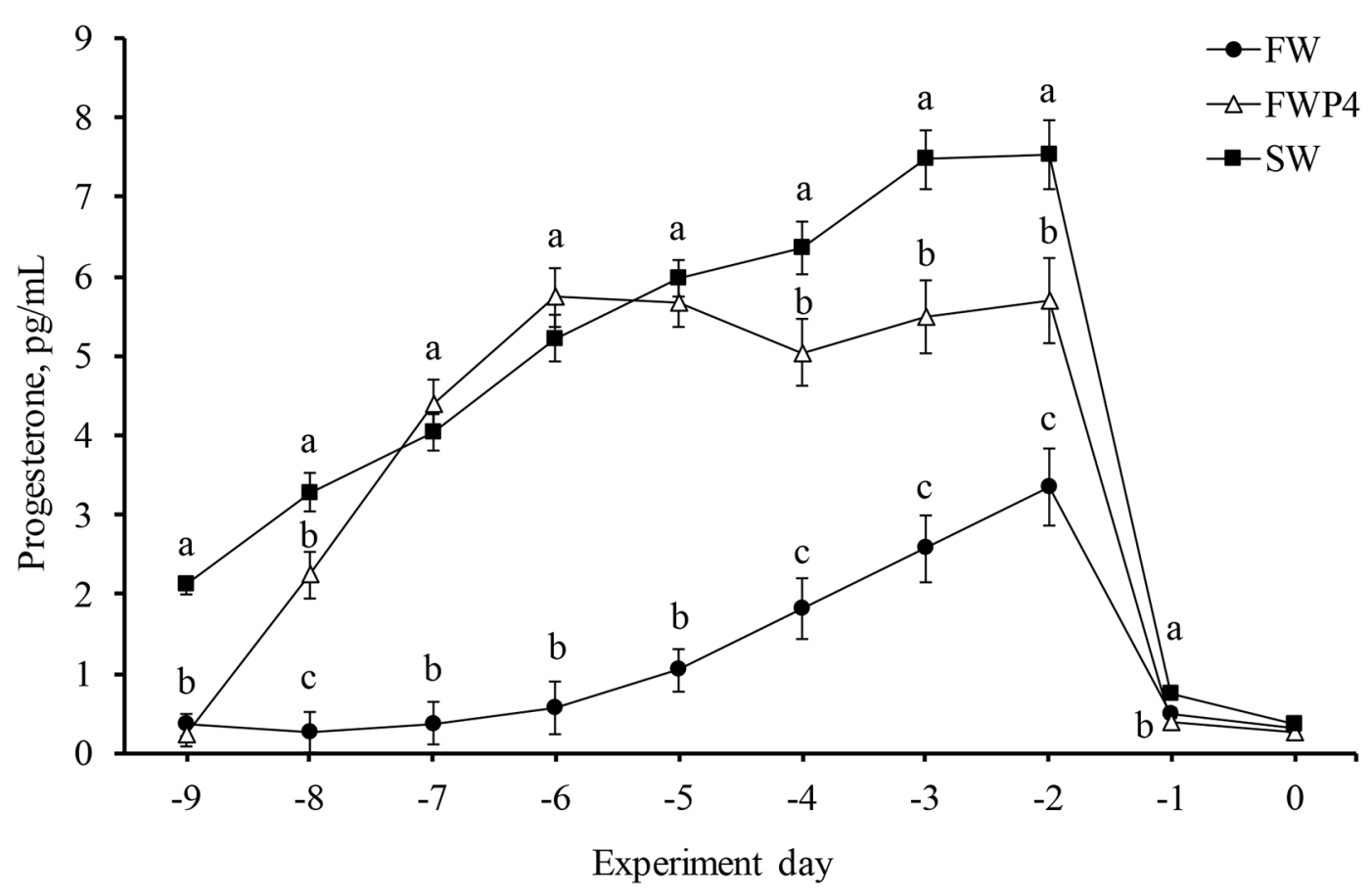

Figure 2. Progesterone concentrations in plasma during the development of the ovulatory follicle (LSM \pm SEM). Cows had the estrous cycle synchronized ( $\mathrm{d}-9 \mathrm{GnRH}, \mathrm{d}-2$ and $-1 \mathrm{PGF}_{2 \alpha}, \mathrm{d} 0 \mathrm{GnRH}$ and $\left.\mathrm{AI} ; \mathrm{d} 0.7 \mathrm{AI}\right)$. FW = cows induced to ovulate first-wave follicles; FWP4 = cows induced to ovulate a first-wave follicle and treated with 3 controlled internal drug release (CIDR) inserts containing $1.38 \mathrm{~g}$ of progesterone each (inserted 12, 24, and $48 \mathrm{~h}$ after GnRH injection on $\mathrm{d}-9$ and removed on $\mathrm{d}-2$ ); SW $=$ cows induced to ovulate second-wave follicles. The mean concentrations of progesterone from $\mathrm{d}-8$ to -2 were: $\mathrm{FW}=1.43 \pm 0.27 ; \mathrm{FWP} 4=4.90 \pm 0.30 ; \mathrm{SW}=5.70 \pm 0.24 \mathrm{ng} / \mathrm{mL}$. Effects of treatment $(P<0.001)$, day $(P<0.001)$, interaction between treatment and day $(P<0.001)$ and effects of progesterone $(P<0.001)$ and follicular wave $(P<0.04)$. Letters a, b, and $\mathrm{c}$ indicate that within day, LSM differed $(P<0.05)$. Error bars represent SEM.

length on $\mathrm{d} 17$ of gestation tended to be greater $(P=$ 0.06 ) for FW compared with FWP4 and SW. The concentration and total amount of IFN- $\tau$ in uterine flush were not affected by progesterone or follicular wave treatments during growth of the ovulatory follicle.

\section{Conceptus and Endometrium Transcriptome}

The length of the conceptuses included in the microarray analyses did not differ $(P=0.28)$ among treatments $(\mathrm{FW}=16.2 \pm 2.6 ; \mathrm{FWP} 4=12.2 \pm 2.6 ; \mathrm{SW}=$

Table 1. Effect of concentration of progesterone and follicular wave during the development of the ovulatory follicle on ovarian responses and hormonal profiles in dairy cows

\begin{tabular}{|c|c|c|c|c|c|c|}
\hline \multirow[b]{2}{*}{ Response } & \multicolumn{3}{|c|}{ Treatment $^{1}$} & \multicolumn{3}{|c|}{$P$-value ${ }^{2}$} \\
\hline & $\mathrm{FW}$ & FWP4 & SW & TRT & $\mathrm{P} 4$ & Wave \\
\hline \multicolumn{7}{|l|}{ Ovulatory follicle, $\mathrm{mm}$} \\
\hline At $\mathrm{PGF}_{2 \alpha}$ injection $(\mathrm{d}-2)$ & $14.1 \pm 0.6$ & $9.9 \pm 0.7$ & $11.7 \pm 0.6$ & $<0.001$ & $<0.001$ & 0.06 \\
\hline At GnRH injection (d 0) & $19.9 \pm 0.5$ & $15.2 \pm 0.6$ & $15.0 \pm 0.5$ & $<0.001$ & $<0.001$ & 0.80 \\
\hline Peak estradiol concentration, pg/mL & $8.6 \pm 0.5$ & $6.0 \pm 0.6$ & $5.8 \pm 0.5$ & $<0.001$ & $<0.001$ & 0.82 \\
\hline Premature peak of estradiol, ${ }^{3} \%(\mathrm{n} / \mathrm{n})$ & $53.3(8 / 15)$ & $8.3(1 / 12)$ & $0.0(0 / 19)$ & 0.01 & $<0.01$ & 0.74 \\
\hline d 7 & $5.4 \pm 0.4$ & $3.2 \pm 0.4$ & $3.9 \pm 0.3$ & $<0.01$ & $<0.001$ & 0.21 \\
\hline d 13 & $6.9 \pm 0.6$ & $5.0 \pm 0.6$ & $6.4 \pm 0.5$ & 0.09 & 0.10 & 0.10 \\
\hline CL weight on $\mathrm{d} 17, \mathrm{~g}$ & $6.9 \pm 0.3$ & $5.0 \pm 0.4$ & $6.0 \pm 0.3$ & $<0.01$ & $<0.01$ & 0.05 \\
\hline
\end{tabular}

${ }^{1} \mathrm{FW}=$ ovulation of first-wave follicles; FWP4 = ovulation of first-wave follicles and progesterone supplementation during follicular growth; SW $=$ ovulation of second-wave follicles. Responses reported as LSM \pm SEM unless specified.

${ }^{2} \mathrm{TRT}=$ effect of treatment; P4 = effect of progesterone (FW vs. FWP4 $\left.+\mathrm{SW}\right)$; Wave = effect of follicular wave (FWP4 vs. SW).

${ }^{3}$ Cows with the maximal estradiol concentration observed on $\mathrm{d}-1$.

${ }^{4}$ Only cows with corpus luteum (CL) on $\mathrm{d}-2$ were included in the statistical analysis. 


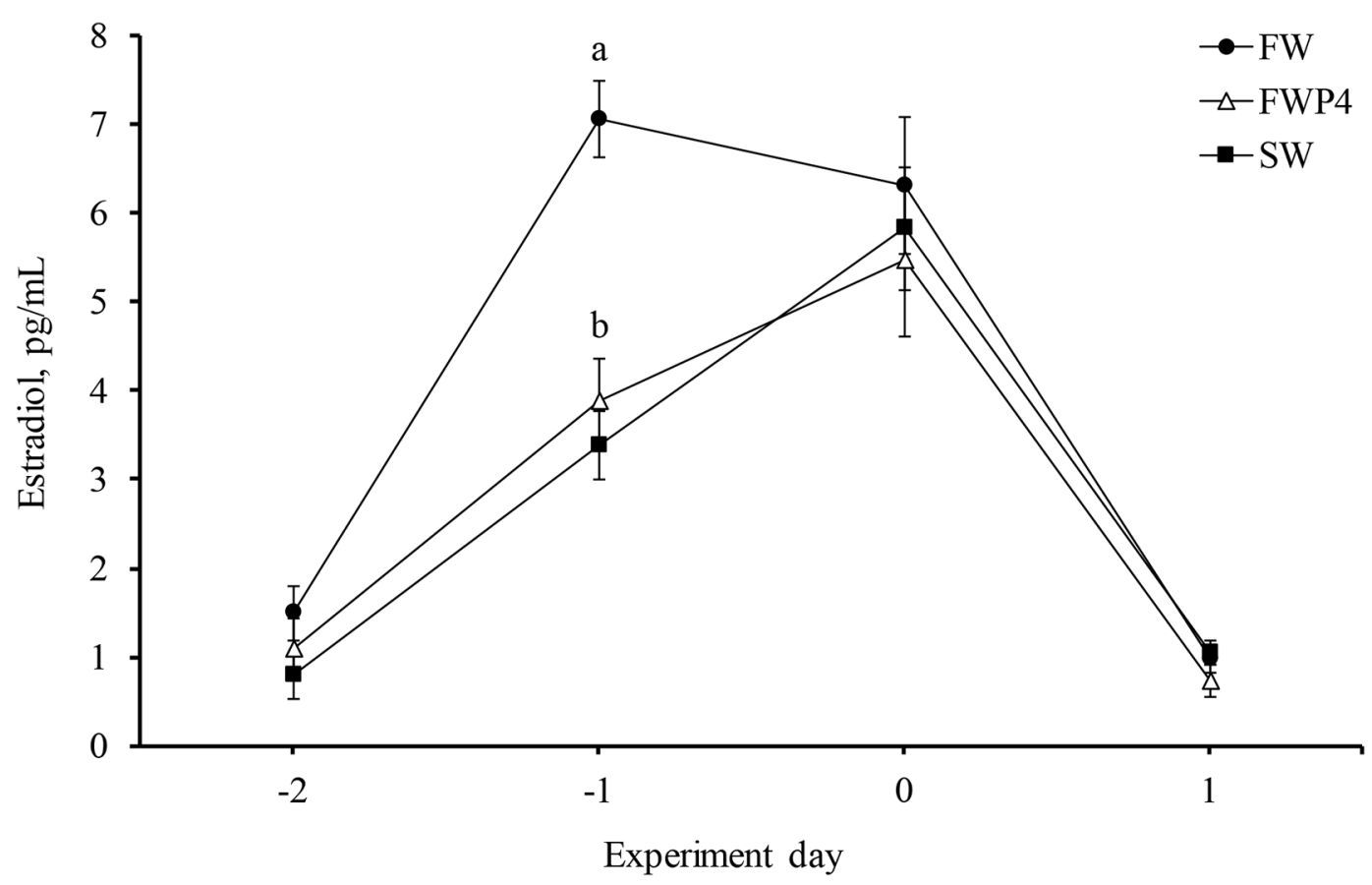

Figure 3. Estradiol concentrations in plasma during proestrus (LSM $\pm \mathrm{SEM}$ ). All cows had the estrous cycle synchronized (d -9 GnRH, d -2 and $-1 \mathrm{PGF}_{2 \alpha}$, d $0 \mathrm{GnRH}$ and $\mathrm{AI}$; d $\left.0.7 \mathrm{AI}\right)$. FW = cows induced to ovulate first-wave follicles; FWP4 = cows induced to ovulate a firstwave follicle and treated with 3 controlled internal drug release (CIDR) inserts containing $1.38 \mathrm{~g}$ of progesterone each (inserted 12, 24, and $48 \mathrm{~h}$ after $\mathrm{GnRH}$ injection on $\mathrm{d}-9$ and removed on $\mathrm{d}-2$ ); $\mathrm{SW}=$ cows induced to ovulate second wave follicles. The mean concentrations of estradiol from $\mathrm{d}-2$ to 1 were: $\mathrm{FW}=3.96 \pm 0.30 ; \mathrm{FWP} 4=2.79 \pm 0.34 ; \mathrm{SW}=2.76 \pm 0.27 \mathrm{pg} / \mathrm{mL}$. Effects of treatment $(P=0.01)$, day $(P<$ 0.001), interaction between treatment and day $(P<0.001)$ and effects of progesterone $(P<0.01)$ and follicular wave $(P=0.94)$. Letters a and $\mathrm{b}$ indicate that within day, effect of progesterone $(P<0.001)$. Error bars represent SEM.

$10.9 \pm 2.1 \mathrm{~cm})$. Neither progesterone (0 differentially expressed genes) nor follicular wave (8 differentially expressed genes) affected extensively the transcriptome of conceptuses on d 17 of gestation (Table 3). Similar to the results observed in the transcriptome analyses of conceptuses, progesterone ( 3 differentially expressed genes) and follicular wave (1 differentially expressed gene) did not have a major influence on endometrial transcriptome on d 17 of gestation (Table 4). No biological process in conceptus and endometrium on $\mathrm{d} 17$ of gestation was significantly affected by follicular wave and progesterone concentration during follicle growth.

\section{DISCUSSION}

Previous experiments have shown that cows induced to ovulate first-wave follicles have reduced concentrations of progesterone in plasma during follicular growth and smaller $\mathrm{P} / \mathrm{AI}$ compared with herdmates that ovulated the dominant follicle from subsequent waves (Bisinotto et al., 2010; Denicol et al., 2012). Understanding the mechanisms that underlie this reduction in fertility is important for the development of strategies to improve reproductive performance in dairy herds. First-wave follicles grew at a faster rate and reached a larger diameter compared with follicles from the second wave, which agrees with previous reports in dairy cows subjected to timed AI programs (Bisinotto et al., 2010) or during a spontaneous estrous cycle (Wolfenson et al., 1995). The effect of treatment on follicle growth also was associated with changes in the pattern of estradiol concentrations in plasma during proestrus. Others have observed no difference in diameter between first- and second-wave dominant follicles in heifers exhibiting 2 waves (Savio et al., 1988; Ginther et al., 1989). This inconsistency can be partially explained by differences in the duration of follicle growth between waves (Ginther et al., 1989). In the present experiment, the emergence of the first and second waves was synchronized using GnRH and occurred on the same day in all treatments, as confirmed by ultrasonography. In addition, follicles from first and second waves were allowed to grow for the same period of time until induction of luteolysis with $\mathrm{PGF}_{2 \alpha}$ and were exposed to the same length of proestrus determined by the final injection of GnRH. Therefore, current outcomes can be attributed exclusively to follicular wave and the stage of the estrous cycle in which the ovulatory follicle developed. Supplementing progesterone during the first wave reduced the diameter of the ovulatory follicle and altered the 


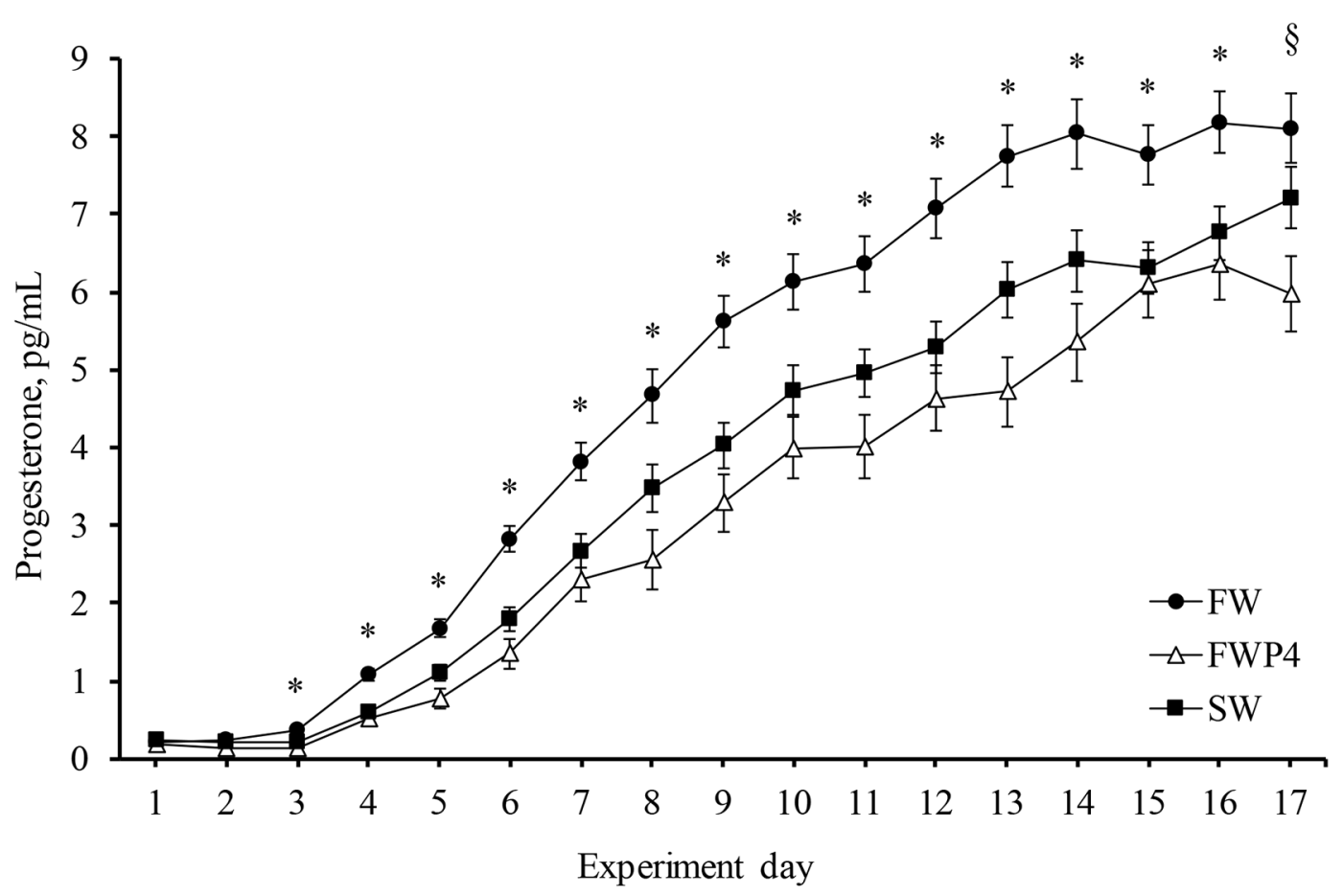

Figure 4. Progesterone concentrations in plasma after ovulation (LSM \pm SEM). Cows had the estrous cycle synchronized (d -9 GnRH, $d-2$ and $-1 \mathrm{PGF}_{2 \alpha}, \mathrm{d} 0 \mathrm{GnRH}$ and $\left.\mathrm{AI} ; \mathrm{d} 0.7 \mathrm{AI}\right)$. FW = cows induced to ovulate first-wave follicles; FWP4 = cows induced to ovulate a first-wave follicle and treated with 3 controlled internal drug release (CIDR) inserts containing $1.38 \mathrm{~g}$ of progesterone each (inserted 12,24 , and $48 \mathrm{~h}$ after GnRH injection on $d-9$ and removed on $d-2)$; SW $=$ cows induced to ovulate second wave follicles. The mean concentrations of progesterone from $\mathrm{d} 1$ to 17 were: $\mathrm{FW}=4.70 \pm 0.31 ; \mathrm{FWP} 4=3.08 \pm 0.34 ; \mathrm{SW}=3.64 \pm 0.27 \mathrm{ng} / \mathrm{mL}$. Effects of treatment $(P<0.001)$, day $(P<0.001)$, interaction between treatment and day $(P<0.001)$ and effects of progesterone $(P<0.001)$ and follicular wave $(P=0.07)$. $*$ indicates LSM were greater $(P<0.03)$ in FW compared with FWP4 and SW. $\S$ indicates LSM were greater $(P<0.01)$ in FW compared with FWP4. Error bars represent SEM.

pattern of estradiol concentrations during proestrus, which did not differ between waves when progesterone was supplemented in FWP4 compared with SW. These results corroborate previous reports suggesting that the reduction in fertility observed in cows induced to ovulate first-wave follicles is mediated by insufficient concentrations of progesterone during follicle growth (Rivera et al., 2011; Bisinotto et al., 2013, 2015).

The changes in diameter of the ovulatory follicle and estradiol concentrations during proestrus were likely caused by increased LH pulsatility in cows with low concentrations of progesterone during follicle growth.

Table 2. Effect of concentration of progesterone and follicular wave during the development of the ovulatory follicle on conceptus development and IFN- $\tau$ in uterine flush

\begin{tabular}{|c|c|c|c|c|c|c|}
\hline \multirow[b]{2}{*}{ Response } & \multicolumn{3}{|c|}{ Treatment $^{1}$} & \multicolumn{3}{|c|}{$P$-value ${ }^{2}$} \\
\hline & FW & FWP4 & SW & TRT & $\mathrm{P} 4$ & Wave \\
\hline \multicolumn{7}{|l|}{ Conceptus length, cm } \\
\hline Range & 4.4 to 26.4 & 0.4 to 23.0 & 0.4 to 22.0 & - & - & - \\
\hline Length of intact conceptuses ${ }^{3}$ & $16.2 \pm 2.7$ & $9.6 \pm 3.1$ & $9.9 \pm 2.2$ & 0.17 & 0.06 & 0.94 \\
\hline Concentration of IFN- $\tau, \mu \mathrm{g} / \mathrm{mL}$ & $1.9 \pm 0.7$ & $1.9 \pm 0.7$ & $0.7 \pm 0.6$ & 0.27 & 0.48 & 0.17 \\
\hline
\end{tabular}

${ }^{1}$ Cows had the estrous cycle synchronized (d -9: GnRH, d -2 and -1: $\mathrm{PGF}_{2 \alpha}$, d 0: GnRH and AI; d 0.7: AI); FW = ovulation of first-wave follicles; FWP4 = ovulation of first-wave follicles and supplementation with exogenous progesterone from $\mathrm{d}-9$ to -2 ; SW $=$ ovulation of secondwave follicles. Responses indicated as LSM \pm SEM unless specified.

${ }^{2} \mathrm{TRT}=$ effect of treatment; P4 = effect of progesterone (FW vs. FWP4 + SW); Wave = effect of follicular wave (FWP4 vs. SW).

${ }^{3}$ Conceptuses that were fragmented upon visual evaluation on d 17 were excluded from statistical analyses. 
Table 3. Effect of concentration of progesterone and follicular wave during the development of the ovulatory follicle on conceptus transcriptome on $\mathrm{d} 17$ of gestation $^{1}$

\begin{tabular}{|c|c|c|c|c|}
\hline Item $^{2}$ & Entrez ID & Gene name & $\mathrm{FC}^{3}$ & Adj. $P^{4}$ \\
\hline \multicolumn{5}{|c|}{$\begin{array}{l}\text { Effect of progesterone concentration during } \\
\text { follicle growth (FW vs. FWP } 4+\mathrm{SW})^{5} \\
\text { None }\end{array}$} \\
\hline SLC45A2 & 538746 & Solute carrier family 45, member 2 & 0.14 & $1.19 \mathrm{E}-02$ \\
\hline STEAP1 & 515156 & $\begin{array}{l}\text { Six transmembrane epithelial antigen of the } \\
\text { prostate } 1\end{array}$ & 0.20 & $4.88 \mathrm{E}-02$ \\
\hline$A M A C R$ & 540376 & Alpha-methylacyl-CoA racemase & 0.39 & $3.62 \mathrm{E}-02$ \\
\hline CA9 & 511923 & Carbonic anhydrase IX & 0.43 & $2.12 \mathrm{E}-02$ \\
\hline$B D P 1$ & 55814 & $\begin{array}{l}\text { B Double Prime 1, Subunit of RNA } \\
\text { Polymerase III Transcription }\end{array}$ & 0.51 & $3.58 \mathrm{E}-03$ \\
\hline PITRM1 & 513230 & Pitrilysin metallopeptidase 1 & 2.16 & $5.84 \mathrm{E}-03$ \\
\hline$I G H M$ & 404057 & Immunoglobulin heavy constant $\mathrm{mu}$ & 3.60 & $1.85 \mathrm{E}-03$ \\
\hline
\end{tabular}

${ }^{1}$ Differentially expressed genes with adjusted $P \leq 0.05$ and fold change $\geq 1.5$, either up- or downregulated for a particular comparison.

${ }^{2} \mathrm{FW}=$ ovulation of first-wave follicles; FWP $4=$ ovulation of first-wave follicles and supplementation with exogenous progesterone from $\mathrm{d}-9$ to $-2 ; \mathrm{SW}=$ ovulation of second-wave follicles.

${ }^{3} \mathrm{FC}=$ fold change compared with the reference group.

${ }^{4} P$-value adjusted for multiple hypothesis testing using the Benjamini and Hochberg method to allow for a maximal false discovery rate of $5 \%$. ${ }^{5} \mathrm{FW}$ is the treatment used as reference.

${ }^{6} \mathrm{FWP} 4$ is the treatment used as reference.

The frequency of LH pulses decreases as progesterone concentrations in plasma increase throughout the estrous cycle, leading to greater LH pulsatility during the period in which the first wave develops (Endo et al., 2012; Santos et al., 2016). The effects of supplementing progesterone to dairy cows using multiple intravaginal inserts on the frequency of LH pulses have not been evaluated. Anovular cows treated with a single insert had fewer LH pulses compared with untreated controls during the first day of treatment, but not $4 \mathrm{~d}$ after the device insertion (Nation et al., 2000). The use of 3
CIDR inserts increased concentrations of progesterone in nonlactating cows by $3.1 \mathrm{ng} / \mathrm{mL}$ during the first follicle wave in FWP4 compared with FW cows. More importantly, progesterone concentrations in FWP4 cows were above $5.0 \mathrm{ng} / \mathrm{mL}$ on $\mathrm{d}-2$, immediately before insert withdraw. It is possible that the use of multiple inserts maintains circulating concentrations of progesterone that are sufficient to reduce LH pulsatility during growth of the ovulatory follicle. In fact, treatment of heifers with injectable progesterone sustained concentration in plasma of $3.5 \mathrm{ng} / \mathrm{mL}$ above that of

Table 4. Effect of concentration of progesterone and follicular wave during the development of the ovulatory follicle on endometrial transcriptome on 17 of gestation $^{1}$

\begin{tabular}{|c|c|c|c|c|}
\hline Item $^{2}$ & Entrez ID & Gene name & $\mathrm{FC}^{3}$ & Adj. $P^{4}$ \\
\hline \multicolumn{5}{|l|}{$\begin{array}{l}\text { Effect of progesterone concentration during } \\
\text { follicle growth (FW vs. FWP } 4+\mathrm{SW})^{5}\end{array}$} \\
\hline PHLDA1 & 540135 & $\begin{array}{l}\text { Pleckstrin homology-like domain, family A, } \\
\text { member } 1\end{array}$ & 1.82 & $7.86 \mathrm{E}-03$ \\
\hline TNFSF10 & 507215 & $\begin{array}{l}\text { Tumor necrosis factor (ligand) superfamily, } \\
\text { member } 10\end{array}$ & 2.22 & $3.82 \mathrm{E}-02$ \\
\hline GIMAP8 & 531516 & GTPase, IMAP family member 8 & 5.89 & $3.02 \mathrm{E}-05$ \\
\hline
\end{tabular}

${ }^{1}$ Differentially expressed genes with adjusted $P \leq 0.05$ and fold change $\geq 1.5$, either up- or downregulated for a particular comparison.

${ }^{2} \mathrm{FW}=$ ovulation of first-wave follicles; FWP $4=$ ovulation of first-wave follicles and supplementation with exogenous progesterone from $\mathrm{d}-9$ to $-2 ; \mathrm{SW}=$ ovulation of second-wave follicles.

${ }^{3} \mathrm{FC}=$ fold change compared with the reference group.

${ }^{4} P$-value adjusted for multiple hypothesis testing using the Benjamini and Hochberg method to allow for a maximal false discovery rate of $5 \%$. ${ }^{5} \mathrm{FW}$ is the treatment used as reference.

${ }^{6} \mathrm{FWP} 4$ is the treatment used as reference. 
controls and reduced the diameter of the first-wave follicle without shortening the period of follicle dominance (Adams et al., 1992). Reducing the frequency of LH pulses during the development of the first-wave follicle is expected to optimize oocyte maturation and, thereby, improve embryo survival (Santos et al., 2016).

Previous studies with beef cattle support that exposure to estradiol during proestrus is critical for priming of the endometrium before establishment of pregnancy (Jinks et al., 2013; Perry et al., 2020), which would favor establishment of pregnancy in FW compared with FWP4 and SW in the present study. Nevertheless, the benefits from prolonging proestrus and supplementing cows with estradiol are linked to inadequate follicular development, reduced ovulatory follicle diameter, and insufficient estradiol synthesis. Premature increase in circulating estradiol and greater preovulatory concentration of estradiol in FW cows was observed concurrent with larger follicle diameter compared with FWP4 ad SW. Concentrations of IGF-1 in the follicular fluid were lesser in dairy cows whose follicles grew under low progesterone concentrations (Cerri et al., 2011a). The oocytes enclosed in persistent follicles display early resumption of meiosis and germinal vesicle breakdown, supposedly because of excessive exposure to LH (Revah and Butler, 1996). This advancement in oocyte maturation might hasten depletion of maternal RNA and reduce fertility (Yu et al., 2001, 2004).

In the present experiment, FW cows had greater CL volume on $\mathrm{d} 7$ and a faster rise in circulating concentrations of progesterone after ovulation compared with FWP4 and SW cows. Even though in vitro production of progesterone by luteinized theca cells was 2 - to 3 -fold greater in cells derived from first compared with second-wave follicles, no difference in progesterone output was observed in luteinized granulosa cells (Wolfenson et al., 1999). Because granulosa cells give rise to large luteal cells and become responsible for 80 to $90 \%$ of the production of progesterone by the CL (Fitz et al., 1982; Farin et al., 1986), the increase in progesterone concentration observed in FW cows early after ovulation was likely a consequence of larger ovulatory follicles with increased number of granulosa cells that resulted in a larger CL volume on $\mathrm{d} 7$ (Vasconcelos et al., 2001). The increase in progesterone after ovulation evident starting on $\mathrm{d} 4$ likely underlies the difference in conceptus length on d 17 of gestation, which was longer for FW cows compared with FWP4 and SW counterparts. Similar results were obtained when anovular cows were compared with estrous cyclic cows (Ribeiro et al., 2016b). After synchronization of the estrous cycle, anovular cows ovulated a larger follicle, formed a larger CL, had greater concentrations of progesterone after
AI, and had larger conceptuses on d 15 after AI than estrous cyclic cows (Ribeiro et al., 2016b). Development of bovine embryos after hatching from the zona pellucida (i.e., d 9-10) is highly dependent on growth factors and nutrients secreted by the endometrial glands, most of which are stimulated by progesterone (Bazer et al., 2008; Filant and Spencer, 2014). A faster rise in progesterone concentrations after ovulation has been associated with increased conceptus length in cattle and supplementation with progesterone via intravaginal inserts resulted in longer conceptus compared with untreated controls (Mann and Lamming, 2001; Carter et al., 2008). Despite the difference in conceptus length, transcriptome analyses of the conceptuses did not depict major shifts in gene expression in response to progesterone concentrations during growth of the ovulatory follicle. Progression of embryo development during elongation and implantation occurs coincident with massive changes in gene expression (Mamo et al., 2011; Valour et al., 2014; Barnwell et al., 2016; Ribeiro et al., 2016a). Although the mean length was greater for FW compared with FWP4 and SW, conceptuses classified as small $(0.4-6.9 \mathrm{~cm} ; \mathrm{FW}=1 / 8$; FWP4 $=$ $4 / 9 ; \mathrm{SW}=6 / 13)$, medium $(10.5-16.0 \mathrm{~cm} ; \mathrm{FW}=4 / 8$; FWP4 $=3 / 9 ; \mathrm{SW}=4 / 13)$, and large $(18.0-26.4 \mathrm{~cm}$; $\mathrm{FW}=3 / 8 ; \mathrm{FWP} 4=2 / 9 ; \mathrm{SW}=3 / 13)$ were observed in all treatments and possibly contributed to offset the effect of treatment on the anticipated changes in transcriptome analyses.

Among the several processes implicated with successful establishment of pregnancy in cattle, bovine conceptuses must be able to elongate rapidly and block the luteolytic cascade by secreting copious amounts of IFN-T (Thatcher et al., 1989). Contrary to the initial hypotheses, low concentrations of progesterone in plasma during the growth of the ovulatory follicle did not delay conceptus elongation and had no effect on the expression of genes associated with embryonic development, IFN- $\tau$ concentration in the uterine flush, or endometrial expression of genes associated with the establishment of pregnancy on d 17 of gestation. Indeed, conceptuses recovered from FW cows tended to be longer compared with those from FWP4 and SW cows, a difference likely attributed to the faster rise in progesterone concentrations after $\mathrm{AI}$ in $\mathrm{FW}$ than FWP4 or SW. Collectively, these results indicate that reproductive failure in cows induced to ovulate firstwave follicles occur either before conceptus elongation and maintenance of the CL for pregnancy or during implantation past d 17 of gestation. Based on studies wherein cows had the uterus flushed for embryo collection, reduced concentrations of progesterone during the growth of the ovulatory follicle did not impair fertiliza- 
tion (Cunha et al., 2008; Rivera et al., 2011). However, morphological evaluation of embryos collected on $\mathrm{d} 7$ after AI indicated a greater proportion of degenerated embryos in cows whose ovulatory follicles developed under low progesterone concentrations (Cunha et al., 2008). The proportion of degenerated embryos harvested $7 \mathrm{~d}$ after AI also was greater in cows subjected to superstimulation with FSH during the first wave compared with cows treated during the second wave (Rivera et al., 2011). Interestingly, supplementation with progesterone restored embryo quality in cows that were superstimulated during the first follicular wave (Rivera et al., 2011). It is reasonable to speculate that the changes in follicle maturation observed in cows with low concentration of progesterone increase embryo mortality during the first 2 wk of gestation. On the other hand, conceptuses that survive until d 17 are able to undergo elongation and implantation similarly to those from cows with elevated concentrations of progesterone during follicle growth. In fact, pregnancy per embryo transfer and the risk of pregnancy loss between $d 21$ and 63 of gestation did not differ for transferable embryos (i.e., good quality) produced after ovulation of follicles that grew under low or high concentrations of progesterone (Rivera et al., 2011).

Endometrial gene expression on d 17 of gestation was not altered in a major manner by concentration of progesterone or follicular wave during follicle growth, which is supported by the observation that conceptuses in all treatments were able to elongate. It has been reported previously that nonpregnant cows with reduced progesterone concentration during the growth of the ovulatory follicle have increased release of $\mathrm{PGF}_{2 \alpha}$ in response to oxytocin (Shaham-Albalancy et al., 2001; Cerri et al., 2011a). It is important to highlight that such studies were conducted with non-inseminated cows, whereas all cows subjected to analyses of endometrial transcriptome in the present experiment were pregnant. Nevertheless, expression of genes that encode for components of the luteolytic cascade were not altered in FW compared with FWP4 and SW endometria, likely because of the effect of IFN- $\tau$ suppressing the pulsatile release of $\mathrm{PGF}_{2 \alpha}$ (Thatcher et al., 1989). In addition to the transcriptome analysis, spontaneous luteolysis before d 17 was not observed in the present experiment. Although treatment essentially did not affect endometrial gene expression in pregnant cows, changes in transcriptome might be associated with reproductive failure in cows from which a conceptus was not recovered. Because all cows were inseminated, it is not possible to determine to what extent the endometrium of nonpregnant cows on d 17 was exposed to an embryo. Accordingly, endometrial tissues from nonpregnant cows on $\mathrm{d} 17$ were not evaluated in this experiment and additional research is needed to evaluate the effects of concentration of progesterone and follicle wave during pre-ovulatory follicle growth on endometrial transcriptome after ovulation.

It is important to highlight that the present experiment was performed using nonlactating dairy cows, as opposed to previous experiments that evaluated the effect of follicular wave and progesterone concentration during growth of the ovulatory follicle on fertility responses in lactating females (Bisinotto et al., 2010, 2013; Rivera et al., 2011). Lactating dairy cows have lesser concentrations of progesterone during diestrus compared with heifers (Sartori et al., 2004), which has been linked to increased feed intake and greater hepatic blood flow leading to more extensive catabolism of steroid hormones (Sangsritavong et al., 2002). On the other hand, recent studies described greater concentrations of progesterone in peripheral blood during mid-diestrus in nonlactating dairy cows compared with lactating counterparts (Endo et al., 2012, 2013). Despite using a model with dry dairy cows, results from this experiment remain relevant to explore the mechanisms underlying reduced fertility in lactating dairy cows following ovulation of follicles that grow under insufficient progesterone support. Data from cows lacking CL at the first GnRH injection of the Ovsynch protocol that received exogenous progesterone suggest that a minimum mean concentration of $2 \mathrm{ng} / \mathrm{mL}$ is necessary to influence fertility responses (Bisinotto et al., 2015). Although the number of cows available for subgroup analyses was limited, the same authors did not find evidence of decreased fertility as the mean progesterone concentrations increased between 5 and $9 \mathrm{ng} / \mathrm{mL}$. Accordingly, FW cows had progesterone concentrations in plasma consistently below $2 \mathrm{ng} / \mathrm{mL}$ whereas FWP4 and SW cows maintained progesterone concentrations between 5 and $8 \mathrm{ng} / \mathrm{mL}$ (i.e., means from $4.9-5.7 \mathrm{ng} / \mathrm{mL}$ ) from $\mathrm{d}-8$ to -2 . Progesterone concentrations in FWP4 reached a plateau on $\mathrm{d}-6$ and were lesser compared with SW from d -4 to -2 . It is possible that suppression of LH pulsatility by exogenous progesterone impaired CL formation in FWP4 cows. Similar differences in progesterone concentrations between metestrus and diestrus are associated with reduced LH pulse frequency in dairy cows (Endo et al., 2012). Moreover, exposure to LH after ovulation is key for adequate luteal morphology, number of small luteal cells, angiogenesis, progesterone content, and expression of steroidogenic enzymes in sheep (Farin et al., 1990; Juengel et al., 1995a,b). As similar patterns of progesterone concentrations were observed in experiments with lactating dairy cows wherein supplementation was effective in improving fertility outcomes (Bisinotto et 
al., 2013, 2015), results from the present experiment provide relevant insights on the mechanisms controlling reproductive efficiency in dairy cattle.

\section{CONCLUSIONS}

Inadequate concentrations of progesterone during the development of the first wave increased the diameter of the ovulatory follicle and altered the pattern of estradiol concentrations during proestrus, which led to the formation of a larger CL and a faster rise in concentrations of progesterone after ovulation. On the other hand, many of those responses were no longer observed once first-wave cows received supplemental progesterone, thereby resembling those that developed the second-wave pre-ovulatory follicle. The length of conceptus on d 17 of gestation was longer for cows in which the ovulatory follicle developed under low concentrations of progesterone. However, progesterone concentration and follicular wave during follicle growth did not affect the amount of IFN- $\tau$ recovered in the uterine flush or the transcriptome of conceptuses and endometrium of pregnant cows.

\section{ACKNOWLEDGMENTS}

The authors thank William Rembert and the Central Beef Industries LLC administration and staff for their assistance for collection of reproductive tracts; managers and staff at University of Florida Dairy Unit for their assistance with animal handling and feeding; and Mariana R. Carvalho, João Vítor S. Queiroz, Ronaldo L. A. Cerri, Sha Tao, Milerky C. Perdomo, Izabella M. Thompson, Luiz Siqueira, Paula Tríbulo, Gabriel C. Gomes, Maurício G. Favoreto, Ana P. Monteiro, and Ana L. Sevarolli (University of Florida, Gainesville) for their assistance with sample processing. Funding for this project was provided by grants from the USDANIFA \#2015-67015-23313 and the Southeast Milk Check-Off Dairy Research and Education Projects to J.E.P. Santos. The authors have not stated any conflicts of interest.

\section{REFERENCES}

Adams, G. P., R. L. Matteri, and O. J. Ginther. 1992. Effect of progesterone on ovarian follicles, emergence of follicular waves and circulating follicle-stimulating hormone in heifers. J. Reprod. Fertil. 96:627-640. https://doi.org/10.1530/jrf.0.0960627.

Barnwell, C. V., P. W. Farin, C. W. Ashwell, W. T. Farmer, S. P. Galphin Jr., and C. E. Farin. 2016. Differences in mRNA populations of short and long bovine conceptuses on day 15 of gestation. Mol. Reprod. Dev. 83:424-441. https://doi.org/10.1002/mrd.22640.

Bazer, F. W., R. C. Burghardt, G. A. Johnson, T. E. Spencer, and G. Wu. 2008. Interferons and progesterone for establishment and maintenance of pregnancy: Interactions among novel cell signaling pathways. Reprod. Biol. 8:179-211. https://doi.org/10.1016/S1642 $-431 \mathrm{X}(12) 60012-6$.

Benjamini, Y., and Y. Hochberg. 1995. Controlling the false discovery rate: A practical and powerful approach to multiple testing. J. R. Stat. Soc. B 57:289-300. https://doi.org/10.1111/j.2517-6161.1995 .tb02031.x.

Bisinotto, R. S., L. O. Castro, M. B. Pansani, C. D. Narciso, N. Martinez, L. D. Sinedino, T. L. Pinto, N. S. Van de Burgwal, H. M. Bosman, R. S. Surjus, W. W. Thatcher, and J. E. P. Santos. 2015. Progesterone supplementation to lactating dairy cows without a corpus luteum at initiation of the Ovsynch protocol. J. Dairy Sci. 98:2515-2528. https://doi.org/10.3168/jds.2014-9058.

Bisinotto, R. S., R. C. Chebel, and J. E. P. Santos. 2010. Follicular wave of the ovulatory follicle and not cyclic status influences fertility of dairy cows. J. Dairy Sci. 93:3578-3587. https://doi.org/10 .3168/jds.2010-3047.

Bisinotto, R. S., E. S. Ribeiro, F. S. Lima, N. Martinez, L. F. Greco, L. F. S. P. Barbosa, P. P. Bueno, L. F. S. Scagion, W. W. Thatcher, and J. E. P. Santos. 2013. Targeted progesterone supplementation improves fertility in lactating dairy cows without a corpus luteum at the initiation of the timed artificial insemination protocol. J. Dairy Sci. 96:2214-2225. https://doi.org/10.3168/jds.2012-6038.

Bisinotto, R. S., E. S. Ribeiro, and J. E. P. Santos. 2014. Synchronisation of ovulation for management of reproduction in dairy cows. Animal 8:151-159. https://doi.org/10.1017/S1751731114000858.

Carter, F., N. Forde, P. Duffy, M. Wade, T. Fair, M. A. Crowe, A. C. O. Evans, D. A. Kenny, J. F. Roche, and P. Lonergan. 2008 Effect of increasing progesterone concentration from day 3 of pregnancy on subsequent embryo survival and development in beef heifers. Reprod. Fertil. Dev. 20:368-375. https://doi.org/10.1071/ RD07204.

Cerri, R. L. A., R. C. Chebel, F. Rivera, C. D. Narciso, R. A. Oliveira, M. Amstalden, G. M. Baez-Sandoval, L. J. Oliveira, W. W. Thatcher, and J. E. P. Santos. 2011a. Concentration of progesterone during the development of the ovulatory follicle: II. Ovarian and uterine responses. J. Dairy Sci. 94:3352-3365. https://doi.org/ $10.3168 /$ jds.2010-3735.

Cerri, R. L. A., R. C. Chebel, F. Rivera, C. D. Narciso, R. A. Oliveira, W. W. Thatcher, and J. E. P. Santos. 2011b. Concentration of progesterone during the development of the ovulatory follicle: I. Ovarian and embryonic responses. J. Dairy Sci. 94:3342-3351. https:// doi.org/10.3168/jds.2010-3734.

Cunha, A. P., J. N. Guenther, M. J. Maroney, J. O. Giordano, A. B. Nascimento, S. Bas, H. Ayres, and M. C. Wiltbank. 2008. Effects of high vs. low progesterone concentrations during Ovsynch on double ovulation rate and pregnancies per AI in high producing dairy cows. J. Dairy Sci. 91(E-Supp. 1):246.

Denicol, A. C., G. Lopes Jr., L. G. D. Mendonça, F. A. Rivera, F. Guagnini, R. V. Perez, J. R. Lima, R. G. Bruno, J. E. P. Santos, and R. C. Chebel. 2012. Low progesterone concentration during the development of the first follicular wave reduces pregnancy per insemination of lactating dairy cows. J. Dairy Sci. 95:1794-1806. https://doi.org/10.3168/jds.2011-4650.

Eijssen, L. M. T., M. Jaillard, M. E. Adriaens, S. Gaj, P. J. de Groot, M. Müller, and C. T. Evelo. 2013. User-friendly solutions for microarray quality control and pre-processing on ArrayAnalysis.org. Nucleic Acids Res. 41(W1):W71-W76. https://doi.org/10.1093/ nar/gkt293.

Elanco Animal Health. 2009. The 5-point Body Condition Scoring System. Elanco Animal Health.

Endo, N., K. Nagai, T. Tanaka, and H. Kamomae. 2012. Comparison between lactating and nonlactating dairy cows on follicular growth and corpus luteum development, and endocrine patterns of ovarian steroids and luteinizing hormone in the estrous cycles. Anim. Reprod. Sci. 134:112-118. https://doi.org/10.1016/j.anireprosci .2012.08.018.

Endo, N., K. Nagai, T. Tanaka, and H. Kamomae. 2013. Changes in plasma progesterone levels in the caudal vena cava and the jugular vein and luteinizing hormone secretion pattern after feeding in lactating and non-lactating dairy cows. J. Reprod. Dev. 59:107-114 https://doi.org/10.1262/jrd.2012-129. 
Farin, C. E., C. L. Moeller, H. R. Sawyer, F. Gamboni, and G. D. Niswender. 1986. Morphometric analysis of cell types in the ovine corpus luteum throughout the estrous cycle. Biol. Reprod. 35:1299-1308. https://doi.org/10.1095/biolreprod35.5.1299.

Farin, C. E., T. M. Nett, and G. D. Niswender. 1990. Effects of luteinizing hormone on luteal cell populations in hypophysectomized ewes. J. Reprod. Fertil. 88:61-70. https://doi.org/10.1530/jrf.0 .0880061

Filant, J., and T. E. Spencer. 2014. Uterine glands: Biological roles in conceptus implantation, uterine receptivity and decidualization. Int. J. Dev. Biol. 58:107-116. https://doi.org/10.1387/ijdb .130344 ts.

Fitz, T. A., M. H. Mayan, H. R. Sawyer, and G. D. Niswender. 1982. Characterization of two steroidogenic cell types in the ovine corpus luteum. Biol. Reprod. 27:703-711. https://doi.org/10.1095/ biolreprod27.3.703.

Forde, N., F. Carter, T. Fair, M. A. Crowe, A. C. O. Evans, T. E. Spencer, F. W. Bazer, R. McBride, M. P. Boland, P. O'Gaora, P. Lonergan, and J. F. Roche. 2009. Progesterone-regulated changes in endometrial gene expression contribute to advanced conceptus development in cattle. Biol. Reprod. 81:784-794. https://doi.org/ 10.1095/biolreprod.108.074336.

Gifford, C. A., A. M. Assiri, M. C. Satterfield, T. E. Spencer, and T. L. Ott. 2008. Receptor transporter protein 4 (RTP4) in endometrium, ovary, and peripheral blood leukocytes of pregnant and cyclic ewes. Biol. Reprod. 79:518-524. https://doi.org/10.1095/ biolreprod.108.069468.

Gifford, C. A., K. Racicot, D. S. Clark, K. J. Austin, T. R. Hansen, M. C. Lucy, C. J. Davies, and T. L. Ott. 2007. Regulation of interferon-stimulated genes in peripheral blood leukocytes in pregnant and bred, nonpregnant dairy cows. J. Dairy Sci. 90:274-280. https: //doi.org/10.3168/jds.S0022-0302(07)72628-0.

Ginther, O. J., L. Knopf, and J. P. Kastelic. 1989. Temporal associations among ovarian events in cattle during oestrous cycles with two and three follicular waves. J. Reprod. Fertil. 87:223-230. https: //doi.org/10.1530/jrf.0.0870223.

Huang, D. W., B. T. Sherman, and R. A. Lempicki. 2009. Systematic and integrative analysis of large gene lists using DAVID bioinformatics resources. Nat. Protoc. 4:44-57. https://doi.org/10.1038/ nprot.2008.211.

Jinks, E. M., M. F. Smith, J. A. Atkins, K. G. Pohler, G. A. Perry, M. D. Macneil, A. J. Roberts, R. C. Waterman, L. J. Alexander, and T. W. Geary. 2013. Preovulatory estradiol and the establishment and maintenance of pregnancy in suckled beef cows. J. Anim. Sci. 91:1176-1185. https://doi.org/10.2527/jas.2012-5611.

Johnson, W. E., C. Li, and A. Rabinovic. 2007. Adjusting batch effects in microarray expression data using empirical Bayes methods. Biostatistics 8:118-127. https://doi.org/10.1093/biostatistics/kxj037.

Juengel, J. L., B. M. Meberg, A. M. Turzillo, T. M. Nett, and G. D. Niswender. 1995a. Hormonal regulation of messenger ribonucleic acid encoding steroidogenic acute regulatory protein in ovine corpora lutea. Endocrinology 136:5423-5429. https://doi.org/10 .1210 /endo.136.12.7588291.

Juengel, J. L., T. M. Nett, T. M. Tandeski, D. C. Eckery, H. R. Sawyer, and G. D. Niswender. 1995b. Effect of luteinizing hormone and growth hormone on luteal development in hypophysectomized ewes. Endocrine 3:323-326. https://doi.org/10.1007/BF03021414.

Mamo, S., J. P. Mehta, P. McGettigan, T. Fair, T. E. Spencer, F. W. Bazer, and P. Lonergan. 2011. RNA sequencing reveals novel gene clusters in bovine conceptuses associated with maternal recognition of pregnancy and implantation. Biol. Reprod. 85:1143-1151. https://doi.org/10.1095/biolreprod.111.092643.

Mann, G. E., and G. E. Lamming. 2001. Relationship between maternal endocrine environment, early embryo development and inhibition of the luteolytic mechanism in cows. Reproduction 121:175180. https://doi.org/10.1530/rep.0.1210175.

McCoski, S. R., M. Xie, E. B. Hall, P. M. Mercadante, T. E. Spencer, P. Lonergan, and A. D. Ealy. 2014. Validation of an interferon stimulatory response element reporter gene assay for quantifying type I interferons. Domest. Anim. Endocrinol. 47:22-26. https:// doi.org/10.1016/j.domaniend.2013.12.003.
Nation, D. P., C. R. Burke, G. Parton, R. Stevenson, and K. L. Macmillan. 2000. Hormonal and ovarian responses to a 5-day progesterone treatment in anoestrous dairy cows in the third week postpartum. Anim. Reprod. Sci. 63:13-25. https://doi.org/10.1016/ S0378-4320(00)00164-0.

O'Hara, L., N. Forde, A. K. Kelly, and P. Lonergan. 2014. Effect of bovine blastocyst size at embryo transfer on day 7 on conceptus length on day 14: Can supplementary progesterone rescue small embryos? Theriogenology 81:1123-1128. https://doi.org/10.1016/j .theriogenology.2014.01.041.

Perry, G. A., R. A. Cushman, B. L. Perry, A. K. Schiefelbein, E. J. Northrop, J. J. J. Rich, and S. D. Perkins. 2020. Role of preovulatory concentrations of estradiol on timing of conception and regulation of the uterine environment in beef cattle. Syst Biol Reprod Med 66:12-25. https://doi.org/10.1080/19396368.2019.1695979.

Revah, I., and W. R. Butler. 1996. Prolonged dominance of follicles and reduced viability of bovine oocytes. J. Reprod. Fertil. 106:3947. https://doi.org/10.1530/jrf.0.1060039.

Ribeiro, E. S., L. F. Greco, R. S. Bisinotto, F. S. Lima, W. W. Thatcher, and J. E. P. Santos. 2016a. Biology of preimplantation conceptus at the onset of elongation in dairy cows. Biol. Reprod. 94:97. https://doi.org/10.1095/biolreprod.115.134908.

Ribeiro, E. S., A. P. A. Monteiro, R. S. Bisinotto, F. S. Lima, L. F. Greco, A. D. Ealy, W. W. Thatcher, and J. E. P. Santos. 2016b. Conceptus development and transcriptome at preimplantation stages in lactating dairy cows of distinct genetic groups and estrous cyclic statuses. J. Dairy Sci. 99:4761-4777. https://doi.org/ 10.3168/jds.2015-10315.

Rivera, F. A., L. G. D. Mendonça, G. Lopes Jr., J. E. P. Santos, R. V. Perez, M. Amstalden, A. Correa-Calderon, and R. C. Chebel. 2011. Reduced progesterone concentration during growth of the first follicular wave affects embryo quality but has no effect on embryo survival post transfer in lactating dairy cows. Reproduction 141:333-342. https://doi.org/10.1530/REP-10-0375.

Sangsritavong, S., D. K. Combs, R. Sartori, L. E. Armentano, and M. C. Wiltbank. 2002. High feed intake increases liver blood flow and metabolism of progesterone and estradiol- $17 \beta$ in dairy cattle. J. Dairy Sci. 85:2831-2842. https://doi.org/10.3168/jds.S0022 $-0302(02) 74370-1$.

Santos, J. E. P., R. S. Bisinotto, and E. S. Ribeiro. 2016. Mechanisms underlying reduced fertility in anovular dairy cows. Theriogenology 86:254-262. https://doi.org/10.1016/j.theriogenology.2016.04 .038 .

Santos, J. E. P., W. W. Thatcher, R. C. Chebel, R. L. Cerri, and K. N. Galvao. 2004. The effect of embryonic death rates in cattle on the efficacy of estrus synchronization programs. Anim. Reprod. Sci. 82-83:513-535. https://doi.org/10.1016/j.anireprosci.2004.04.015.

Sartori, R., J. M. Haughian, R. D. Shaver, G. J. M. Rosa, and M. C. Wiltbank. 2004. Comparison of ovarian function and circulating steroids in estrous cycles of Holstein heifers and lactating cows. J. Dairy Sci. 87:905-920. https://doi.org/10.3168/jds.S0022 -0302(04)73235-X.

Savio, J. D., L. Keenan, M. P. Boland, and J. F. Roche. 1988. Pattern of growth of dominant follicles during the oestrous cycle of heifers. J. Reprod. Fertil. 83:663-671. https://doi.org/10.1530/jrf .0 .0830663 .

Shaham-Albalancy, A., Y. Folman, M. Kaim, M. Rosenberg, and D. Wolfenson. 2001. Delayed effect of low progesterone concentrations on bovine uterine PGF(2alpha) secretion in the subsequent oestrous cycle. Reproduction 122:643-648. https://doi.org/10.1530/ rep.0.1220643.

Shaham-Albalancy, A., A. Nyska, M. Kaim, M. Rosenberg, Y. Folman, and D. Wolfenson. 1997. Delayed effect of progesterone on endometrial morphology in dairy cows. Anim. Reprod. Sci. 48:159-174. https://doi.org/10.1016/S0378-4320(97)00037-7.

Siddiqui, M. A. R., E. L. Gastal, M. O. Gastal, M. Almamun, M. A. Beg, and O. J. Ginther. 2009. Relationship of vascular perfusion of the wall of the preovulatory follicle to in vitro fertilisation and embryo development in heifers. Reproduction 137:689-697. https:/ /doi.org/10.1530/REP-08-0403. 
Smyth, G. K. 2004. Linear models and empirical bayes methods for assessing differential expression in microarray experiments. Stat. Appl. Genet. Mol. Biol. 3:3.

Spencer, T. E., N. Forde, P. Dorniak, T. R. Hansen, J. J. Romero, and P. Lonergan. 2013. Conceptus-derived prostaglandins regulate gene expression in the endometrium prior to pregnancy recognition in ruminants. Reproduction 146:377-387. https://doi.org/10 .1530/REP-13-0165.

Spencer, T. E., O. Sandra, and E. Wolf. 2008. Genes involved in conceptus-endometrial interactions in ruminants: insights from reductionism and thoughts on holistic approaches. Reproduction 135:165-179. https://doi.org/10.1530/REP-07-0327.

Thatcher, W. W., P. J. Hansen, T. S. Gross, S. D. Helmer, C. Plante, and F. W. Bazer. 1989. Antiluteolytic effects of bovine trophoblast protein-1. J. Reprod. Fertil. Suppl. 37:91-99.

Valour, D., S. A. Degrelle, A. A. Ponter, C. Giraud-Delville, E. Campion, C. Guyader-Joly, C. Richard, F. Constant, P. Humblot, C. Ponsart, I. Hue, and B. Grimard. 2014. Energy and lipid metabolism gene expression of D18 embryos in dairy cows is related to dam physiological status. Physiol. Genomics 46:39-56. https://doi .org/10.1152/physiolgenomics.00091.2013.

Vasconcelos, J. L. M., R. Sartori, H. N. Oliveira, J. G. Guenther, and M. C. Wiltbank. 2001. Reduction in size of the ovulatory follicle reduces subsequent luteal size and pregnancy rate. Theriogenology 56:307-314. https://doi.org/10.1016/S0093-691X(01)00565-9.

Wiltbank, M. C., G. M. Baez, A. Garcia-Guerra, M. Z. Toledo, P. L. J. Monteiro, L. F. Melo, J. C. Ochoa, J. E. P. Santos, and R. Sartori. 2016. Pivotal periods for pregnancy loss during the first trimester of gestation in lactating dairy cows. Theriogenology 86:239-253. https://doi.org/10.1016/j.theriogenology.2016.04.037.

Wiltbank, M. C., A. H. Souza, P. D. Carvalho, A. P. Cunha, J. O Giordano, P. M. Fricke, G. M. Baez, and M. G. Diskin. 2014. Physiological and practical effects of progesterone on reproduction in dairy cattle. Animal 8(Suppl. 1):70-81. https://doi.org/10 $.1017 /$ S1751731114000585.
Wolfenson, D., H. Sonego, A. Shaham-Albalancy, Y. Shpirer, and R. Meidan. 1999. Comparison of the steroidogenic capacity of bovine follicular and luteal cells, and corpora lutea originating from dominant follicles of the first or second follicular wave. J. Reprod. Fertil. 117:241-247. https://doi.org/10.1530/jrf.0.1170241.

Wolfenson, D., W. W. Thatcher, L. Badinga, J. D. Savio, R. Meidan, B. J. Lew, R. Braw-Tal, and A. Berman. 1995. Effect of heat stress on follicular development during the estrous cycle in lactating dairy cattle. Biol. Reprod. 52:1106-1113. https://doi.org/10.1095/ biolreprod52.5.1106.

Wu, Z., R. A. Irizarry, R. Gentleman, F. Martinez-Murillo, and F. Spencer. 2004. A model-based background adjustment for oligonucleotide expression arrays. J. Am. Stat. Assoc. 99:909-917. https:/ /doi.org/10.1198/016214504000000683.

Yu, J., M. Deng, S. Medvedev, J. Yang, N. B. Hecht, and R. M. Schultz. 2004. Transgenic RNAi-mediated reduction of MSY2 in mouse oocytes results in reduced fertility. Dev. Biol. 268:195-206. https://doi.org/10.1016/j.ydbio.2003.12.020.

Yu, J., N. B. Hecht, and R. M. Schultz. 2001. Expression of MSY2 in mouse oocytes and preimplantation embryos. Biol. Reprod. 65:1260-1270. https://doi.org/10.1095/biolreprod65.4.1260.

\section{ORCIDS}

R. S. Bisinotto $\odot$ https://orcid.org/0000-0001-6144-2919

E. S. Ribeiro ๑ https://orcid.org/0000-0002-4201-7383

A. D. Ealy (으 https://orcid.org/0000-0002-8507-6578

F. S. Lima $\odot$ https://orcid.org/0000-0001-8377-6469

N. Martinez (1) https://orcid.org/0000-0001-9022-8452

W. W. Thatcher ๑ https://orcid.org/0000-0001-6866-3431

J. E. P. Santos ๑ https://orcid.org/0000-0003-3403-1465 